\title{
Patient Satisfaction Survey in City Hospital: Case of Isparta
}

\author{
Deniz GÜNEŞ ${ }^{1}$, Mihriban GÜDER ${ }^{2}$, Özge ÖZDİNÇ ${ }^{3}$, Erdal EKE ${ }^{4}$
}

\begin{tabular}{|c|c|}
\hline & ABSTRACT \\
\hline $\begin{array}{r}\text { DOI } \\
\text { https://10.48121/jihsam.791436 } \\
\\
\text { Received } \\
07.09 .2020 \\
\text { Accepted } \\
17.11 .2020 \\
\text { Published Online } \\
25.12 .2020\end{array}$ & $\begin{array}{l}\text { Patient satisfaction is an important issue in terms of the } \\
\text { quality and performance of health institutions. In this } \\
\text { study, the patient satisfaction levels of the city hospitals, } \\
\text { which were brought to the agenda within the scope of the } \\
\text { Health Transformation Program and built with the Public- } \\
\text { Private Partnership (PPP) model, were examined. The aim } \\
\text { of this study is to determine the level of satisfaction of } \\
\text { Isparta City Hospital patients and to determine the } \\
\text { relationship between the demographic characteristics of } \\
\text { the participants and the physical environment, general } \\
\text { satisfaction, staff satisfaction and time sub-dimensions for } \\
\text { patient satisfaction level. The sample of the study consists } \\
\text { of } 275 \text { participants who receive service from the city } \\
\text { hospital in Isparta province. The patient satisfaction } \\
\text { questionnaire, which Gökkaya, Izgüden and Erdem (2018) } \\
\text { used in their studies, was used as a data collection tool in } \\
\text { the study. The data obtained within the scope of the study } \\
\text { were analyzed with the SPSS Statistics } 22 \text { program. As a } \\
\text { result of the normality test, the "t Test" and "ANOVA } \\
\text { Test", which are among the parametric tests, were used in } \\
\text { the data that was suitable for normal distribution. It has } \\
\text { been examined in four different dimensions as patient } \\
\text { satisfaction, physical environment, general satisfaction, } \\
\text { staff satisfaction and time. It was observed that the } \\
\text { participants were satisfied with the general quality of the } \\
\text { city hospital in these four dimensions. Participants } \\
\text { expressed their satisfaction especially with the cleanliness, } \\
\text { hygiene and the new and spaciousness of the building. On } \\
\text { the other hand, it has been revealed that factors such as } \\
\text { waiting in line, confusion and size in the hospital, not } \\
\text { getting enough information and parking lot are decreasing } \\
\text { the level of patient satisfaction. }\end{array}$ \\
\hline
\end{tabular}

\footnotetext{
Research Assistant, Ordu University, Faculty of Health Science, denizgunes1912@gmail.com, https://orcid.org/0000-0002-1995-8142

2 Master student, Süleyman Demirel University, Faculty of Economics and Administrative Sciences, mihribanguder@ hotmail.com. https://orcid.org/0000-0001-7123-2122

3 Master student, Süleyman Demirel University, Faculty of Economics and Administrative Sciences, ozdincozge.zz@gmail.com. https://orcid.org/0000-0002-9769-7304

4 Assistant Professor, Süleyman Demirel University, Faculty of Economics and Administrative Sciences, erdaleke03@ gmail.com. https://orcid.org/0000-0002-9529-5889
} 


\section{INTRODUCTION}

With the changes in the economic, social and political fields in the last period of the 20th century, there has been a transformation from a state understanding that produces and manages services to a state understanding that directs and regulates economic variables. Along with the transformations of the states, there have been changes in the way states take part in infrastructure services. With these changes, the concept of public-private partnership has emerged and this method has started to be used in the provision of public services, especially in developing countries. This method has paved the way for investments that countries could not afford due to financial problems (Ministry of Development, 2012: $6)$.

The concept of public- private partnership, which has many different definitions in the literature, can be defined as the state's participation of private law persons in the process in the provision of public services as soon as possible (Gürkan, 2014: 1). According to another definition, public- private partnership is a partnership that brings together the public, private sector and non-governmental organizations in the provision of public services, based on the principles of joint management and equality, and in the understanding of new public management, the consequences such as risks, costs and benefits in the production of goods and services are undertaken by all stakeholders method (Kerman et al., 2012: 4). General features of the definition of Public Private Partnership can be listed as follows (Çakır, 2016: 22):

- PPP is based on a contract signed between the public and the private sector in the process of producing and providing public goods and services.

- PPP ensures the participation of the private sector in the provision of public service.

- PPP offers alternative financing methods in the financing of public services.

- PPP is an umbrella concept that includes models such as build-operate-transfer, build-operate, build-lease-transfer.

- Private and public sector share the risks in the production of public goods or services and decision-making process (Forrer, J. et al., 2010: 476).

As a result of these definitions, it is seen that public services are offered with a common benefit between the private sector and the public sector, where the risk is shared and the limits are clearly defined in the public-private partnership. In order to realize these public services in a better quality, efficient and effective way, the talent and business ability and potential of the private sector are transferred to the public sector and cooperation is realized with the prominent features of both sectors (Atasever, 2018: 17).

According to the 2004 Green Paper publication of the European Commission, there are four items to explain features of public- private partnership. These four items are expressed as follows:

1. Including cooperation between public partner and private partner in different parts of the planned project and having a long term partnership relationship.

2. Project is sometimes financed by the private sector and sometimes by various stakeholders.

3. First of all, public partner focus on the achievement of the public interest, and then focus on the quality of the service and focus on the goals to be achieved economically.

4. Generally, there is a risk distribution in which the risks that the public sector may face are transferred to the private partner. However, this item doesn't mean that the private partner will take risks in all projects. Determining the risk taker varies from project to project according to its ability to evaluate and control the risk (European Commission, 2004: 3).

As emphasized in the definitions, public-private partnership is described as an "umbrella concept" and includes many models (Evren, 2016: 347). There are not standard models that are applied everywhere and all the time. In commonly used models are buildoperate-transfer (BOT), build-operate (BO), buildlease-transfer, build-lease-operate, build-own-operatetransfer, revenue partnership model (Sarı̈ürk, 2018: 347).

It is seen that the first examples of public-private partnership projects in the world were used in the 17 th and 18th centuries with the concession method and generally to build construction of canals and bridges. In the 19th century, it is seen that some infrastructure services in Europe were provided by the private sector instead of public sector. In the 20th century, especially after the Second World War, it started to be applied in the construction of road networks in countries such as Italy, France, Japan and the USA (Yusufi Yilmaz and Gültekin Karakaş, 2011: 32). In recent years, it is observed that the number of public-private partnership projects has increased in the provision of infrastructure services investments in developed and developing countries, especially after the 1990s (Ministry of Development, 2012: 8). When we look at the project data of the World Bank with public-private partnership between 1990 and 2018, it is seen that the electricity sector took the first place with 3627 units and a project cost of 910.467 million USD (URL 1, 2019). 
In Turkey, it is observed that the public-private partnership based on the concession procedure dating back to the Ottoman period. Nowadays, with the increasing need for infrastructure projects and limited public resources, interest in public-private partnership is increasing. The public-private partnership, which first came to the agenda with energy projects in 1986, started to be implemented in many sectors such as transportation, energy, education and health with the Law No. 3996 on "Making Certain Investments and Services by Build-Operate-Transfer Model" in 1994. Especially the realization of integrated health campuses (city hospitals) within the scope of "Health Services Basic Law" numbered 3359 with the buildlease model has brought a new direction to publicprivate partnership. According to recent data by the Ministry of Development sector in Turkey ranks first in the number of 94 volume Project is located in the energy sector. In this ranking, there are 42 highways, 23 ports and 20 healthcare sectors after the energy sector (Ministry of Development, 2012: 20-24).

\section{Public Private Partnership in Health Care Services}

Private-public partnership (PPP) is originated when more than two organizations in the public or private sector start a new cooperative relationship based on mutual trust, rather than being characterized by a hierarchical structure (Naoum, 2003). PPP is significantly different from traditional design- bid build contracts. Various definitions can be found in the literature about PPP. The most commonly used definition is "an arrangement between two or more entities that enables them to work cooperatively towards shared or compatible objectives and in which there is some degree of shared authority and responsibility, joint investment of resources, shared risk taking and mutual benefit" (Allan, 1999).

The first practice of the collaboration of public and private commenced with the private sector participation models used for construction of road in 1660s. Especially in the railway and canal projects after the industrial revolution, the use of collaboration of public and private's model came to the highest point particularly in United Kingdom in 1860 s
(Çekirge, 2006: 5). The public-private partnership project, which was first realized in the Ottoman Period, was used in the public transportation system in Istanbul (Çekirge, 2006: 31). Afterwards, in the Republic Period, the public-private partnership model was permitted non-public organization's generating, distributing and trading electricity with the law enacted in 1984 numbered 3096 (Çekirge, 2006: 14).

The use of public-private partnership projects in the field of health is realized with projects called "health city", "integrated health campus" or, most known as "city hospital" (Gökbulut, 2019). In terms of city hospital practices, the Health Services Basic Law numbered 3359 in 1987 can be shown as a comprehensive regulation (Karasu, 2011: 223). An additional 7 th article was added to this law with the law numbered 5396 enacted in 2005. Accordingly, the Ministry of Health has granted real or private law legal entities to establish a health facility in return for leasing, not exceeding 49 years, on the immovables belonging to itself or the treasury (T.C. Official Gazette, 2006). With the Health Transformation Program initiated by the Ministry of Health in 2003, Public Hospital Unions were established and 29 Health Service Regions were determined by considering the transportation possibilities of the region and existing health inventories (Akdağ, 2012: 263).

Today, there are 10 city hospitals with contracts signed and serving. The hospitals actively serving are as follows; Adana City Hospital, Mersin City Hospital, Isparta City Hospital, Yozgat City Hospital, Kayseri City Hospital, Manisa City Hospital, Elazig City Hospital, Ankara Bilkent City Hospital, Eskişehir City Hospital and Bursa City Hospital. In addition to these hospitals, Ankara Etlik City Hospital, Konya Karatay Hospital, Gaziantep City Hospital, Tekirdağ Health Campus, Kütahya City Hospital, Kocaeli City Hospital, İmir Bayraklı City Hospital and Istanbul Íkitelli City Hospital are the hospitals planned to be opened in 2020. Şanliurfa Health Campus and Psychiatry and High Security Forensic Psychiatry Hospitals are planned to be opened in 2021 (URL 2, 2019).

\section{MATERIALS AND METHODS}

The aim of this study is to determine the level of satisfaction of Isparta City Hospital patients and to determine the relationship between the demographic characteristics of the patients and the physical environment, general satisfaction, staff satisfaction and time sub-dimensions for patient satisfaction level.

The problem sentence of the study is "what is the satisfaction level of the patients with the city hospital they receive service?".

The population of this study is the people of Isparta. The sample consists of 275 participants who receive service from Isparta City Hospital, which is selected through convenience sampling. One of the quantitative research techniques, face to face survey method was used for randomly selected participants.

The data collection tool of this study is the patient satisfaction questionnaire used by Gökkaya, İzgüden and Erdem (2018) in their studies. The patient satisfaction questionnaire consists of "physical environment, general satisfaction, staff satisfaction and time" sub-dimensions. The analysis and interpretation of the data were made within the scope of sub-dimensions. The data collection tool is 5-point 
Likert scale. It is scaled within the score range of "1" strongly disagree and "5" strongly agree. The questionnaire includes 25 statements, 1 open-ended question and 5 questions for demographic information. During the analysis phase of the study, the survey data were transferred to the computer using the SPSS package program. The data were coded properly in the program and made ready for analysis, and the analyzes were analyzed with the SPSS Statistics 22 program. Parametric tests were used for the data that was suitable for normal distribution as a result of the normality test. "T test" was used to determine the difference between groups with two variables, and "analysis of variance (ANOVA)" was used to determine the difference between groups with three and more variables. "Tukey's-b test" was used to determine the difference between groups in the ANOVA test.

\section{Findings}

As a result of the normality test, the Kurtosis and Skewness values of 25 items were found to be in the range of -1.96 to +1.96 , so they were suitable for normal distribution.

Table 1. Reliability Analysis

\begin{tabular}{|c|c|c|}
\hline $\begin{array}{c}\text { Cronbach's } \\
\text { Alpha }\end{array}$ & $\begin{array}{c}\text { Cronbach's Alpha } \\
\text { Based on } \\
\text { Standardized Items }\end{array}$ & $\begin{array}{c}\text { N of } \\
\text { Items }\end{array}$ \\
\hline 0,930 & 0,934 & 25 \\
\hline
\end{tabular}

As seen in Table 1, the Cronbach's alpha value of the scale items of the city hospitals patient satisfaction survey was found to be 0.930 and the items were found to be highly reliable.

Table 2. Demographic Characteristics of the Participants

\begin{tabular}{lrr}
\hline Age & Number & \% \\
\hline$<26$ & 83 & 30,2 \\
$26-35$ & 95 & 34,5 \\
$36-45$ & 49 & 17,8 \\
$45<$ & 48 & 17,5 \\
\hline Gender & & \\
Male & 132 & 48,0 \\
Female & 143 & 52,0 \\
\hline Marital Status & & \\
Married & 136 & 49,5 \\
Single & 139 & 50,5 \\
\hline Educational Status & & \\
Primary school & 37 & 13,5 \\
High school & 58 & 21,1 \\
Associate degree & 42 & 15,3 \\
Undergraduate & 107 & 38,9 \\
graduate & 31 & 11,3 \\
\hline Profession & & \\
Government official & 64 & 23,3 \\
Private sector & 90 & 32,7 \\
Tradesmen & 50 & 18,2 \\
Others & 71 & 25,8 \\
\hline Total & $\mathbf{2 7 5}$ & $\mathbf{1 0 0 , 0}$ \\
\hline & &
\end{tabular}

As seen in Table 2, the sample of Isparta, where 275 people were reached, $30.2 \%$ were under 25 years old, $34.5 \%$ were between $26-35$ years old, $17.8 \%$ were between $36-45$ years old, $17,5 \%$ were over 46 years old and $48 \%$ were men and $52 \%$ were women. When we look at the marital status of the sample, it is seen that it is remarkably close to each other and consists of $49.5 \%$ married and $50.5 \%$ unmarried individuals. When we look at the educational status, the biggest part is the undergraduate level. It was observed that $13.5 \%$ of the participants were at primary school, $21.5 \%$ at high school, $15.3 \%$ at associate degree, $38.9 \%$ at undergraduate and $11.3 \%$ at graduate level. Private sector employees have the largest share with $32.7 \%$, government official with $23.3 \%$, other occupational groups (housewives, retirees, workers, students, etc.) and tradesmen with $18.2 \%$, respectively.

Table 3. Arithmetic Mean and Standard Deviation of the Statements Related to the Patient Satisfaction Questionnaire

\begin{tabular}{|c|c|c|c|}
\hline No & Statements & $\overline{\mathbf{x}}$ & SS \\
\hline 1 & $\begin{array}{l}\text { I can easily find the place where I am } \\
\text { looking for in the hospital. }\end{array}$ & 3.272 & 1.420 \\
\hline 2 & $\begin{array}{l}\text { I am satisfied with the hygiene conditions of } \\
\text { city hospitals (polyclinics, clinics, toilets, } \\
\text { waiting areas, etc.) }\end{array}$ & 4.127 & 1.078 \\
\hline 3 & I waited too long in line to be examined. & 3.218 & 1.349 \\
\hline 4 & $\begin{array}{l}\text { Counselling and referral services were } \\
\text { generally good. }\end{array}$ & 3.952 & 1.077 \\
\hline 5 & $\begin{array}{l}\text { I am satisfied with the attitude of the hospital } \\
\text { staff. }\end{array}$ & 3.832 & 1.153 \\
\hline 6 & $\begin{array}{l}\text { Privacy is considered during the } \\
\text { examination. }\end{array}$ & 3.960 & 1.172 \\
\hline 7 & $\begin{array}{l}\text { I am generally satisfied with the service } \\
\text { offered by the hospital. }\end{array}$ & 3.876 & 1.142 \\
\hline 8 & $\begin{array}{l}\text { I am satisfied with the overall quality of the } \\
\text { hospital. }\end{array}$ & 3.927 & 1.091 \\
\hline 9 & $\begin{array}{l}\text { I did not encounter the problem I } \\
\text { experienced in other hospitals in this } \\
\text { hospital. }\end{array}$ & 3.410 & 1.296 \\
\hline 10 & $\begin{array}{l}\text { The physical structure of the hospital } \\
\text { facilitates service procurement. }\end{array}$ & 3.327 & 1.351 \\
\hline 11 & $\begin{array}{l}\text { I have no difficulty in traveling from one } \\
\text { place to another in the hospital. }\end{array}$ & 3.061 & 1.477 \\
\hline 12 & $\begin{array}{l}\text { I am satisfied with the physical appearance, } \\
\text { cleanliness, and spaciousness of the hospital. }\end{array}$ & 4.167 & 1.084 \\
\hline 13 & $\begin{array}{l}\text { I am satisfied with the ease of access to the } \\
\text { hospital. }\end{array}$ & 3.294 & 1.478 \\
\hline 14 & $\begin{array}{l}\text { I am satisfied with the quality of the tools } \\
\text { and equipment used in the hospital }\end{array}$ & 3.901 & 1.117 \\
\hline 15 & $\begin{array}{l}\text { I am satisfied with the comfort of the } \\
\text { examination rooms (heat, light, etc.). }\end{array}$ & 4.138 & 1.030 \\
\hline 16 & $\begin{array}{l}\text { I am satisfied with the parking lot adequacy } \\
\text { of the hospital. }\end{array}$ & 3.134 & 1.511 \\
\hline 17 & $\begin{array}{l}\text { I am glad that the social areas (cafeteria, } \\
\text { canteen etc.) of the hospital meet my needs. }\end{array}$ & 3.545 & 1.281 \\
\hline 18 & $\begin{array}{l}\text { I think enough time has been allocated for } \\
\text { me during the examination. }\end{array}$ & 3.283 & 1.406 \\
\hline 19 & If I need it again, I prefer this hospital. & 3.741 & 1.215 \\
\hline 20 & I recommend the hospital to others. & 3.770 & 1.233 \\
\hline 21 & $\begin{array}{l}\text { I was able to have my tests and examinations } \\
\text { done in a short time. }\end{array}$ & 3.421 & 1.297 \\
\hline 22 & $\begin{array}{l}\text { I am satisfied with the speed of the } \\
\text { procedures in the hospital. }\end{array}$ & 3.367 & 1.249 \\
\hline 23 & $\begin{array}{l}\text { The information I received from the hospital } \\
\text { staff satisfied me. }\end{array}$ & 3.530 & 1.193 \\
\hline 24 & The hospital staff took care of me enough. & 3.596 & 1.205 \\
\hline 25 & I am glad that the city hospital was built. & 3.825 & 1.336 \\
\hline
\end{tabular}


When we look at the Table 3 , it is seen that all the means of the answers given by the participants to the expressions in the questionnaire are higher than 3 . The fact that all the statements' means are higher than 3 and the 25 th statement's mean is 3,825 shows that the participants are satisfied with the construction of the city hospital.

Among the statements, the lowest mean belongs to "I do not have difficulty in traveling from one place to another in the hospital" statement with $\overline{\mathrm{x}}=3.061$. Also, the highest mean belongs to "I am satisfied with the physical appearance, cleanliness and spaciousness of the hospital" statement with $\overline{\mathrm{x}}=4.167$.

\section{Findings of Participants' Answers to Open- ended Questions}

It was observed that the participants who answered the open-ended questions in the questionnaire expressed more negative opinions. Although the satisfaction rate was found high in the analysis, we can infer that those who answered this open-ended question were participants with lower satisfaction levels.

Table 4. Positive Views of the Participants

\begin{aligned} & \hline Variables Number \\ & \hline Everything about city hospital 15 \\ & Cleaning / Hygiene 8 \\ & The building is new and spacious 5 \\ & Satisfaction of service 4 \\ & Personnel attitude 3 \\ & Patient orientation 2 \\ & Travelling in hospital 2 \\ & Quickness of service 1 \\ & Getting services together 1 \\ & Transportations to the hospital 1 \\ & Without waiting in the line 1 \\ & \hline\end{aligned}

When we look at the Table 4, it is seen that 15 people are satisfied with everything about city hospital. Also, it is seen that 8 people are satisfied with the cleanliness and hygiene and 5 people are satisfied with the new and spacious building.

Table 5. Negative Views of the Participants

\begin{aligned} \hline Variables & Numbel \\ \hline Personnel attitude & 19 \\ Transportation to the hospital & 18 \\ Waiting in the line & 16 \\ Hospital size/Confusing in the hospital & 12 \\ Lack of information & 9 \\ Parking Lot & 6 \\ Lack of service & 5 \\ Insufficient examination time & 4 \\ Patient confidentiality & 3 \\ Canteen & 2 \\ Cleaning / Hygiene & 2 \\ Everything & 2 \\ Lack of staff & 2\end{aligned}

When we look at the Table 5, it is seen that participants expressed their negative opinions about Isparta city hospital. 19 participants complain about the personnel attitude, 18 participants about the transportation to the hospital, 16 participants about the waiting time in the line, 12 participants about confusing in the hospital and size of the hospital and 9 participants complain about the healthcare worker (specially physicians).

Table 6. Psychometric Features of Patient Satisfaction Sub-Dimensions

\begin{tabular}{lcccccrr}
\hline Sub-Dimensions & $\begin{array}{c}\text { Number of } \\
\text { Statements }\end{array}$ & $\begin{array}{c}\text { Max/ } \\
\text { Min }\end{array}$ & $\begin{array}{c}\text { Cronbach } \\
\text { Alfa }\end{array}$ & $\overline{\mathbf{x}}$ & SS & $\begin{array}{c}\text { Normality Test } \\
\text { Skewness }\end{array}$ & Kurtosis \\
\hline Physical Environment & 8 & $1-5$ & 0,864 & 3,596 & 0,803 & $-0,285$ & $-0,473$ \\
General satisfaction & 9 & $1-5$ & 0,822 & 3,745 & 0,913 & $-0,547$ & $-0,493$ \\
Staff satisfaction & 4 & $1-5$ & 0,862 & 3,728 & 0,930 & $-0,677$ & $-0,190$ \\
Time & 4 & $1-5$ & 0,882 & 3,322 & 0,838 & $-0,322$ & $-0,228$ \\
\hline
\end{tabular}

In this study, satisfaction levels of the participants were discussed in 4 sub-dimensions. Table 6 contains the values of the sub-dimensions. The 4 subdimensions in the questionnaire are as follows:

Physical Environment Sub-Dimensions: The mean of this sub-dimension, which includes 8 statements, is 3.596 and the standard deviation is 0.803 . Cronbach alpha value was found as 0.864

General satisfaction Sub-Dimensions: The mean of this sub-dimension, which includes 9 statements, is 3,745 and the standard deviation is 0.913 . Cronbach alpha value was found as 0.822 .
Staff Satisfaction Sub-Dimensions: The mean of this sub-dimension, which includes 4 statements, is 3, 728 and the standard deviation is 0. 930. Cronbach alpha value was found as 0.862 .

Time Sub-Dimensions: The mean of this subdimension, which includes 4 statements, is 3, 322 and the standard deviation is 0.838 . Cronbach alpha value was found as 0.862 . It is seen that the dimension with the lowest mean is the time sub-dimension. However, when we look at the four sub-dimensions, it is seen that their means are above 3.20 and it is concluded that the participants are satisfied. 
Table 7. Relationship between sub-dimensions and gender (T Test Analysis)

\begin{tabular}{|c|c|c|c|c|c|}
\hline & \multicolumn{4}{|c|}{ Sub-Dimensions } \\
\hline & & $\begin{array}{c}\text { Physical } \\
\text { Environment }\end{array}$ & $\begin{array}{c}\text { General } \\
\text { satisfaction }\end{array}$ & Staff satisfaction & Time \\
\hline \multirow{2}{*}{ Gender } & Male & $3,55 \pm 0,803$ & $3,71 \pm 0,931$ & $3,67 \pm 0,998$ & $3,31 \pm 0,878$ \\
\hline & Female & $3,63 \pm 0,804$ & $3,77 \pm 0,899$ & $3,77 \pm 0,863$ & $3,32 \pm 0,802$ \\
\hline \multicolumn{2}{|c|}{ Test and value of $p$} & $\begin{array}{l}\mathrm{t}=-0,924 \\
\mathrm{p}=0,356\end{array}$ & $\begin{array}{l}\mathrm{t}=-0,478 \\
\mathrm{p}=0,633\end{array}$ & $\begin{array}{l}\mathrm{t}=-0,891 \\
\mathrm{p}=0,374\end{array}$ & $\begin{array}{l}\mathrm{t}=-0,086 \\
\mathrm{p}=0,931\end{array}$ \\
\hline
\end{tabular}

According to the sub-dimensions of the city hospitals patient satisfaction questionnaire and the results of the gender-based t test analysis, all $\mathrm{p}$ values were found to be higher than 0.05 .

Table 8. Relationship between sub-dimensions and Marital Status (T Test Analysis)

\begin{tabular}{lccccc}
\hline & \multicolumn{4}{c}{ Physical } & \multicolumn{2}{c}{ Sub-Dimensions } \\
Environment & $\begin{array}{c}\text { General } \\
\text { Satisfaction }\end{array}$ & Staff satisfaction & Time \\
\hline Marital & Married & $3,79 \pm 0,714$ & $3,98 \pm 0,846$ & $4,00 \pm 0,830$ & $3,50 \pm 0,848$ \\
Status & Single & $3,40 \pm 0,842$ & $3,51 \pm 0,921$ & $3,45 \pm 0,945$ & $3,14 \pm 0,792$ \\
\hline Test and value of $p$ & $\mathrm{t}=4,061$ & $\mathrm{t}=4,354$ & $\mathrm{t}=5,108$ & $\mathrm{t}=3,580$ \\
& $\mathrm{p}=0,000$ & $\mathrm{p}=0,000$ & $\mathrm{p}=0,000$ & $\mathrm{p}=0,000$ \\
\hline
\end{tabular}

According to the sub-dimensions of the city hospitals patient satisfaction questionnaire and the results of the marital status-based, $\mathrm{p}$ values were found to be less than 0.05 . A significant relationship was observed between marital status and subdimensions, and in all sub-dimensions, the satisfaction levels of those who are married are higher than single participants.

Table 9. ANOVA Test Analysis for Sub-Dimensions

\begin{tabular}{|c|c|c|c|c|c|}
\hline & \multicolumn{4}{|c|}{ Sub-Dimensions } \\
\hline & & $\begin{array}{c}\text { Physical } \\
\text { Environment }\end{array}$ & $\begin{array}{c}\text { General } \\
\text { satisfaction }\end{array}$ & $\begin{array}{c}\text { Staff } \\
\text { satisfaction }\end{array}$ & Time \\
\hline \multirow{4}{*}{ Age } & $-25^{1}$ & $3,50 \pm 0,801$ & $3,60 \pm 0,890$ & $3,58 \pm 0,928$ & $3,26 \pm 0,763$ \\
\hline & $26-35^{2}$ & $3,47 \pm 0,847$ & $3,59 \pm 0,956$ & $3,51 \pm 1,028$ & $3,23 \pm 0,903$ \\
\hline & $36-45^{3}$ & $3,80 \pm 0,714$ & $4,04 \pm 0,735$ & $4,03 \pm 0,609$ & $3,48 \pm 0,813$ \\
\hline & $46+{ }^{4}$ & $3,79 \pm 0,745$ & $3,97 \pm 0,932$ & $4,10 \pm 0,821$ & $3,42 \pm 0,842$ \\
\hline \multirow{3}{*}{\multicolumn{2}{|c|}{ Test and value of $p$}} & $\mathrm{~F}=3,297$ & $\mathrm{~F}=4,414$ & $\mathrm{~F}=7,220$ & $\mathrm{~F}=1,333$ \\
\hline & & $\mathrm{p}=0,021$ & $\mathrm{p}=0,005$ & $\mathrm{p}=0,000$ & $\mathrm{p}=0,264$ \\
\hline & & $3>4^{\mathrm{a}}$ & $3>4^{\mathrm{a}}$ & $4>3^{\mathrm{a}}$ & \\
\hline \multirow{5}{*}{$\begin{array}{l}\text { Education } \\
\text { status }\end{array}$} & Primary School $^{1}$ & $3,96 \pm 0,620$ & $4,34 \pm 0,664$ & $4,35 \pm 0,782$ & $3,72 \pm 0,810$ \\
\hline & High School $^{2}$ & $3,67 \pm 0,835$ & $3,81 \pm 0,859$ & $3,82 \pm 0,883$ & $3,45 \pm 0,782$ \\
\hline & Associate Degree $^{3}$ & $3,60 \pm 0,781$ & $3,67 \pm 1,048$ & $3,63 \pm 1,083$ & $3,39 \pm 0,989$ \\
\hline & Undergraduate $^{4}$ & $3,51 \pm 0,802$ & $3,60 \pm 0,891$ & $3,56 \pm 0,867$ & $3,15 \pm 0,773$ \\
\hline & Graduate $^{5}$ & $3,28 \pm 0,835$ & $3,49 \pm 0,882$ & $3,48 \pm 0,875$ & $3,07 \pm 0,775$ \\
\hline \multirow{3}{*}{\multicolumn{2}{|c|}{ Test and value of $p$}} & $\mathrm{~F}=3,662$ & $\mathrm{~F}=5,732$ & $\mathrm{~F}=6,162$ & $\mathrm{~F}=4,618$ \\
\hline & & $\mathrm{p}=0,006$ & $\mathrm{p}=0,000$ & $\mathrm{p}=0,000$ & $\mathrm{p}=0,001$ \\
\hline & & $1>2^{a}$ & $1>2^{a}$ & $1>2^{a}$ & $1>2^{a}$ \\
\hline \multirow{4}{*}{ Profession } & Government official $^{1}$ & $3,52 \pm 0,824$ & $3,61 \pm 0,819$ & $3,64 \pm 0,849$ & $3,25 \pm 0,753$ \\
\hline & Private Sector $^{2}$ & $3,55 \pm 0,837$ & $3,58 \pm 0,917$ & $3,59 \pm 0,888$ & $3,25 \pm 0,809$ \\
\hline & Tradesman $^{3}$ & $3,56 \pm 0,849$ & $3,74 \pm 1,006$ & $3,66 \pm 1,122$ & $3,32 \pm 0,954$ \\
\hline & Others $^{4}$ & $3,74 \pm 0,699$ & $4,06 \pm 0,854$ & $4,01 \pm 0,859$ & $3,47 \pm 0,857$ \\
\hline \multirow{3}{*}{\multicolumn{2}{|c|}{ Test and value of $p$}} & $\mathrm{~F}=1,107$ & $\mathrm{~F}=4,440$ & $\mathrm{~F}=3,247$ & $\mathrm{~F}=1,103$ \\
\hline & & $\mathrm{p}=0,347$ & $\mathrm{p}=0,005$ & $\mathrm{p}=0,022$ & $\mathrm{p}=0,348$ \\
\hline & & & $4>3^{a}$ & $4>3^{a}$ & \\
\hline
\end{tabular}

Post-Hoc Tests a=Tukey’s-b

When we look at the Table 9, one-way analysis of variance (ANOVA) was applied to observe whether the sub-dimensions of the city hospitals patient satisfaction questionnaire had a significant relationship with their demographic characteristics.
According to the results of the ANOVA test based on age, a significant relationship was found at the subdimensions of physical environment, general satisfaction, and staff satisfaction. It is concluded that 
people aged 36-45 are more satisfied with the physical environment and general satisfaction, and people over the age of 46 are more satisfied about staff.

According to the results of the ANOVA test based on education status, there is a significant relationship between all sub-dimensions. It is seen that people with graduate education level are the group with the lowest level of satisfaction while the satisfaction level of people with primary education is at the highest level. As a result, it is observed that as the level of education increases, the level of satisfaction decreases.
According to the results of the ANOVA test based on profession, a significant relationship is observed between the general satisfaction and staff satisfaction sub-dimensions. There is no significant relationship in the physical environment and time sub-dimension. It is also observed that the satisfaction levels of "others" (workers, unemployed, housewives, retired and students) are the highest in the sub-dimensions of general satisfaction and staff satisfaction.

\section{RESULT}

Public-private partnership model, used in the transportation, education and energy sector, has gained a new direction in the health sector with the "the city hospitals" concept in Turkey. The fact that city hospitals, which are realized with the cooperation of the private sector and the public, provide services at the quality of private hospitals, has led to increase in competition among healthcare institutions. Therefore, it is important for hospitals to keep patient satisfaction levels at a high level.

In this study, physical environment, general satisfaction, staff satisfaction and time were discussed in four different dimensions and patient satisfaction levels were examined. As a result of the study, it was observed that the patients were generally satisfied with the Isparta city hospital. It was observed that the participants were especially satisfied with the physical appearance, cleanliness, spaciousness of the city hospitals, the comfort of the examination rooms and the hygiene conditions. It was observed that the lack of vehicle parking in the hospital, the difficulty in moving from one place to another, the inability to find the place sought in the hospital easily and waiting too long in line to be examined are the factors that reduce the level of satisfaction.

Considering the positive and negative results of the participants about the hospital, it is seen that although the general satisfaction level is high, the number of those who express their negative opinions is higher. It is seen that "satisfaction about everything" has the biggest share among the positive opinions. Cleaning and hygiene conditions and the new and spacious building are the other two factors that get the biggest share among the positive opinions. On the other hand, in the negative opinions, it is seen that the factors such as personnel attitude, transportation to the hospital, long waiting times, confusion and size in the hospital, not getting enough information have a big share.
In this study, it was examined whether the satisfaction levels of the patients in the city hospital differ according to demographic characteristics. According to the analysis results, no relationship was found between gender, which is one of the demographic features, and sub-dimensions. It was found that there is relationship between marital status and all sub-dimensions, and the satisfaction level of the married people in city hospitals was higher.

As a result of the survey, there is a significant relationship between the physical environment dimension, which is one of the sub-dimensions of the questionnaire, and marital status, age and educational status, but not a significant relationship with gender and profession. It has been observed that married participants aged 36-45 and participants with primary education level are more satisfied. There is a significant relationship between general satisfaction sub-dimension and marital status, age, occupation, and educational status, but not with gender sub-dimension. As in the physical environment dimension, it has been observed that married participants between the ages of 36-45 and those whose education level is primary education are more satisfied. There is also a significant relationship between the staff satisfaction sub-dimension and marital status, age, occupation and educational status, and no significant relationship with gender. Participants who are married, over the age of 46 , with primary education and other occupational groups (housewife, retired, worker, student, etc.) are more satisfied. There is a relationship between the time dimension, another sub-dimension of the questionnaire, marital status and educational status, and no significant relationship with gender, age, and profession. It has been observed that married people with primary education level are more satisfied. 


\section{DISCUSSION AND RECOMMENDATION}

The concept of satisfaction is a subjective concept. It has become an important issue in health institutions and organizations in recent years. Patient satisfaction is an important concept in measuring and evaluating the quality of healthcare services. Healthcare institutions take into account the feedback in the parts related to satisfaction today. As a result of increasing competition among health institutions, applications that increase satisfaction are on the agenda in order to be preferred more and to gain the trust of patients (Gökkaya, İzgüden, \& Erdem, 2018: 145).

There are many factors affecting the service quality in the provision of health services. In patient satisfaction studies, it is seen that a system is applied according to the aspects of the physical, psychological, social and economic effects that the patient is satisfied or not satisfied with (Andaleeb, Siddiqui and Khandakar, 2007: 265). In this study, patient satisfaction was examined under 4 different dimensions (physical environment, general satisfaction, staff satisfaction and time dimension).

Since city hospitals are newly included in our lives, it is seen in the literature that patient satisfaction studies in city hospitals are limited. When the patient satisfaction studies in city hospitals are examined, first of all, Gökkaya, İzgüden and Erdem (2018: 145). It is seen that the satisfaction levels of the patients are quite high in patient satisfaction, which was examined in 4 dimensions as physical environment, general satisfaction, staff satisfaction and time dimension in the patient satisfaction research study in Isparta City Hospital. In Ergün's (2019: 86) examination of Yozgat Integrated Health Campuses in terms of patient satisfaction, the patient's staff satisfaction was $72.6 \%$, and the physical area was $77.8 \%$. Overall, the polyclinic satisfaction is $74.4 \%$. Patients receiving service from Yozgat City Hospital are satisfied with hospital. In Sarcan's (2019: 105) patient satisfaction study in Adana City Hospital, patient satisfaction level was evaluated over 5 points. According to the research results, it can be stated that patient satisfaction is high since the average level of patient satisfaction is above 3.40 for cleaning services, administrative support services, catering services, security services, physical conditions, nurse care, emergency service care and doctor care. As a result of the research, it was observed that the satisfaction levels of the patients were generally high. In the survey of service satisfaction of Çınar, Türkoğlu and Tütünsatar (2015: 229), we can see that the satisfaction rate of the patients' queue waiting time item is very low with 2.07. We see that the expression of taking care and care for patients got 2.40 points, and the administrative staff was insufficient with 2.35 . In addition, the fact that the physician, nurse and caregiver score above 3 is an indicator of satisfaction. It is seen that the individuals who participated in the study in the city hospital, which was taken as an example, are generally satisfied.

Nowadays, patient satisfaction is an important issue for all health institutions. With the increasing competitive environment, it is important to increase patient satisfaction levels to attract patients. According to this study, in order to increase patients satisfaction;

1. Actions should be taken especially in order to improve the personnel attitude, which is a negative aspect with the highest frequency.

2. The bus route can be changed provided more frequent bus service by contacting the provincial and district municipalities in order to eliminate the transportation problem to the hospital.

3. More personnel should be employed to eliminate the problem of waiting in line.

\section{REFERENCES}

Akdağ, R. (2012) Türkiye Sağllkta Dönüşüm Programı Değerlendirme Raporu (2003-2011), Sağlık Bakanlığı, 2012: 263

Allan, J. R. (1999) Public -Private Partnerships: A Review of Literature and Practice. Saskatchewan Institute of Public Policy, Public Policy paper n.4.

Andaleeb S, Siddiqui N, Khandakar S. (2007). Patient Satisfaction with Health Services in Bangladesh. Health Policy and Planning, 22(4): 263-273

Atasever, M. (2018). Şehir Hastaneleri Araştırması, Sağlık-Sen Yayınları, Ankara.

European Commission (2004). Green Paper on Public-Private Partnerships and Community Law on Public Contracts and Concessions, Brüksel.

Çakır, M.K. (2016). 6428 Sayll Kanuna Göre Kamu Özel İşbirliği Kavramı ve Yeni Bir Model: Yap-Kirala-Devret, Seçkin Yayıncılık, Ankara.
Çekirge, H. L. (2006). Dünyada ve Türkiye'de Кати Özel Ortakllğl Uygulamalarl ve Örnek Bir Projede Modelin Finansal ve Genel Avantajlarının Değerlendirilmesi. Yayınlanmamış Yüksek Lisans Tezi.

Çınar, N.F., Türkoğlu, Ç., Tütünsatar, A. (2017). Кати-Özel Ortaklığ//Işbirliği Modeli Ve Sağllk Hizmetlerinin Sunumunda Hizmet Memnuniyetinin Ölçülmesi: Entegre Sağllk Kampüsleri (Şehir Hastaneleri) İçin Bir Araştırma, Süleyman Demirel Üniversitesi Sosyal Bilimler Enstitüsü Dergisi, 29(4): 215-232

Ergün Ö. (2019) Türkiye'de Kamu Özel Sektör Ortaklı̆̆ Ile Yapılan Entegre Sağllk Kampüslerinin Hasta Memnuniyeti Açısından İncelenmesi: Yozgat Şehir Hastanesi Örneği. Yüksek Lisans Tezi, Gazi Üniversitesi, Sosyal Bilimler Enstitüsü, Sağlık Yönetimi Anabilim Dalı

Evren, Ç.C. (2016). Кати-Özel İşbirlikleri: Кати Hizmetlerinin Özel Kişilere Sözleşme Yoluyla Gördürülmesinin Hukuki Rejimi, Seçkin Yayıncılık, Ankara. 
Forrer, J., Kee J. E., Newcomer, K. E., Boyer, E., (2010), "Public-Private Partnerships and the Public Accountability Question", Public Administration Review, Volume70, Issue 3

Gökbulut, F. (2019). Türkiye'de Kamu Özel İşbirliğinin Sağllk Alanında Uygulanması: Şehir Hastaneleri. Ankara Üniversitesi. Yüksek Lisans Tezi.

Gökkaya,D., İzgüden,D., Erdem, R. (2018). Şehir Hastanesinde Hasta Memnuniyeti Araştırması: Isparta İli Örneği. Süleyman Demirel Üniversitesi Vizyoner Dergisi, 9(20):136-148

Gürkan, M.F. (2014). Kamu Özel Ortaklığl, Adalet Yayınevi, Ankara.

Karasu, K. (2011). Sağlık Hizmetlerinin Örgütlenmesinde Kamu-Özel Ortaklığl. Ankara Üniversitesi SBF Dergisi, 66(03): 217-262

Kerman, U., Altan, Y., Aktel, M., \& Eke, E. (2012). Să̆lık Hizmetlerinde Kamu Özel Ortaklığ Uygulaması. Süleyman Demirel Üniversitesi İktisadi ve İdari Bilimler Fakültesi Dergisi, 17(3), 1-23.

Ministry of Development, (2012). Dünyada ve Türkiye'de Kamu-Özel İşbirliği Uygulamalarına İlişkin Gelişmeler, Yatırım Programlama İzleme ve Değerlendirme Genel Müdürlüğü, Ankara.
Naoum, S, (2003). An overview into the concept of partnering. International journal of project management, 21(1), 71-76.

Sarcan E. (2019). Adana Şehir Hastanesi'nde Hasta Memnuniyetine Yönelik Bir Araştırma, Yüksek Lisans Tezi, Ankara Üniversitesi Sağlık Bilimleri Enstitüsü, Ankara.

Sarıtürk, M. (2018). Kamu Özel Ortaklı̆̆l, Editör: Kıyal Kamchybekova ABDİRAIM, International Conference on Management and Social Sciences: Proceeding Book

T.C. Resmi Gazete. (2006).

URL 1: The World Bank. https://ppi. worldbank.org/en/snapshots/rankings Access Date: 25.12.2019

URL 2, Sağlık Bakanlığı https://sygm.saglik.gov.tr/TR,33960/sehir-hastaneleri.html Access Date: 20.12 .2019

Yusufi Yılmaz, F., \& Gültekin Karakaş, D. (2011). Girişimci Cumhurbaşkanı, Girişimci Vali. Girişimci Rektör Sağlıkta Kamu Özel Ortaklı̆̆’nın Yapısal/Konjonktürel ve Türkiye'ye Özgü Nedenleri, Sağlık Alanında Kamu-Özel Ortaklığı Sempozyumu, 32. 